\title{
MLL/MAML2 Fusion Protein
}

National Cancer Institute

\section{Source}

National Cancer Institute. MLL/MAML2 Fusion Protein. NCI Thesaurus. Code C99358.

A fusion protein encoded by the MLL/MAML2 fusion gene. This protein is comprised of the $\mathrm{N}$-terminal half of the histone-lysine $\mathrm{N}$-methyltransferase $\mathrm{MLL}$ protein, including the AT hook DNA binding domain and the DNA methyltransferase domain, fused to the Cterminal acidic and glutamine-rich domains of mastermind-like protein 2. 